\title{
The Effect of Transformational Leadership, Organizational Culture and Organization Commitment on Employee Job Satisfaction in Small Medium Enterprise of Automotive Service
}

\author{
Agus Arijanto ${ }^{1}$ \\ ${ }^{1}$ Economic \& Business Faculty, Universitas Mercu Buana Jakarta, and Postgraduate Student Programme of \\ Doctor of Management Science Universitas Jenderal Soedirman Purwokerto Central Java, Indonesia \\ ${ }^{1}$ agus.arijanto@mercubuana.ac.id \\ DOI: 10.47760/cognizance.2021.v01i06.002
}

\begin{abstract}
The study aims to analyze the influence of Transformational Leadership, Organizational Culture, and Organizational Commitment on the Job Satisfaction. The research object is a sample used as many as 90 employees of PT. Heriromadiali, calculated based on the use of saturated samples. Method of collecting data using survey method, with research instrument is questionnaire. The characteristic analysis method of respondents uses the Statistical Package for the Social Sciences (SPSS) and data analysis methods using Partial Least Square (PLS). Research proves that the. Transformational Leadership has a positive and significant to Job Satisfaction. Organizational Culture have positive and significant effect on Job Satisfaction, and Organizational Commitment has a significant and positive effect on Employee Job Satisfaction in Small Medium Enterprise Automotive Services

Keywords: Transformational Leadership, Organizational Culture, Organizational Commitment, Job Satisfaction
\end{abstract}

\section{INTRODUCTION}

Human resources are the most important factors that influence or play an important role in achieving the company's vision, mission, and goals. Poor management of human resources will cause employee discomfort at work so that what employees produce for their work will be deemed less useful for the company, therefore good human resource management is needed, therefore it will create a conducive working atmosphere, so that employees can produce high productivity that can advance the company. Potential human resources if utilized effectively and efficiently will be useful.

The company cannot be separated from the important role of employees, because employees can be a determinant of the success of a company or organization. Therefore, employees are not only required to have the ability and knowledge, they must also have commitment and loyalty to the company, so that if the employee's performance in the company is good, the company's performance will also provide progress for the company. Companies need to know the performance and job satisfaction of their employees, so that companies can retain their employees, and besides that employees can also be used as good main partners in supporting the success of a company (Jumadi et al., 2018)

Job satisfaction is an important thing that individuals have at work. Each individual worker has different characteristics, so the level of job satisfaction is different and the level of job satisfaction can have an unequal impact. For organizations, employee job satisfaction must receive attention and fulfillment of this is primarily the task of organizational leaders. For employees, job satisfaction is an individual factor and a means to achieve work productivity. So within the scope of human resource management, job satisfaction factors provide benefits for organizations or companies, employees, and even for the community (Ramli and Soelton, 2018). In a business organization the character of a leader and the style applied in his leadership have a huge influence on the running of the organization and the survival of the organization as one of the determinants of success in achieving the mission, vision and goals of an organization. Efforts to improve employee performance cannot be separated from the attention of leaders in providing motivation, as well as employee satisfaction, so understanding job satisfaction is very important. Leadership models such as transformational leadership are leadership approaches by making efforts to change awareness, raise the spirit of subordinates or members of the organization without feeling pressured or pressured. Subordinates feel trust, admiration, loyalty and respect for 


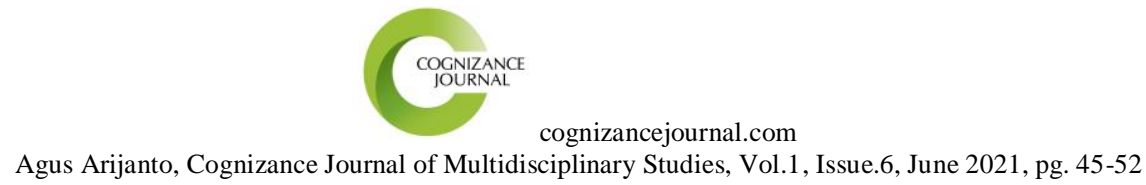

ISSN: 0976-7797

their superiors. Transformational leadership involves developing a closer relationship between leaders and followers, not just an agreement but more based on trust and commitment.

A strong organizational culture supports the company's goals. Every organization has different customs and cultures. An organization has a good organizational culture, if the culture that applies to the organization concerned applies good habits. Therefore, many companies are competing to build organizational culture by making positive changes to improve their performance. To build a strong organizational culture requires a process because the changes that occur in the organization involve changes in the people who are in the organization including differences in perceptions, desires, attitudes, and behaviors. It can be understood that organizational culture has a very important role in increasing job satisfaction. Organizational commitment shows a person's power in identifying his involvement in a part of the organization. Organizational commitment is built on the basis of workers' trust in the values of the organization, the willingness of workers to help realize organizational goals and loyalty to remain members of the organization. If the worker feels himself bound by the existing organizational values, he will feel happy at work, so that his performance can increase. In an organization there is also a belief that organizational commitment can increase job satisfaction.

Literature Review, Framework for Thinking and Development

Transformational Leadership Transformational leadership is often defined by its impact on how leaders reinforce attitudes of mutual cooperation and trust, collective self-efficacy, and team learning. Transformational leaders make their followers become more aware of the importance and value of work and persuade followers not to prioritize personal interests over organizational interests (Rahmi, 2014). Dimensions and Indicators of Transformational Leadership Rahmi (2014) suggests that there are four characteristics as well as dimensions of transformational leadership: 1) Idealist Influence (Individualized Influence), the leader sets high standards of behavior, morals and ethics, and uses the ability to mobilize individuals and groups for mutual achievement. 2) Inspirational Motivation, the leader acts as a model or role model for followers, communicates vision, commitment to organizational goals, and directs followers' efforts. 3) Intellectual Stimulation, the leader stimulates subordinates to think creatively and innovatively, by assuming questions, redesigning past problems to be solved by subordinates in new ways. Leaders are proactive, creative and innovative in taking ideas, have a radical ideology and search for ideas in solving problems. 4) Individualized Consideration, the leader personally gives personal attention to subordinates by acting as a mentor, this is to increase the needs and abilities of subordinates to a higher level. Transactional Leadership Indicators Rahmi (2014) suggests that transformational leadership can be measured by the following indicators: 1) Idealist Influence a) Setting High Standards of Conduct b) Setting High Standards of Morals and Ethics c) Mobilizing Individuals or Groups for Common Achievements 2) Inspirational Motivation a) Vision Implementation b) Role Model for Subordinates 3) Intellectual Stimulation a) Provide stimulation to subordinates to be creative and innovative b) Have a strong ideology 4) Individual Considerations a) Give personal attention to subordinates

Leadership, through personal influence and behavior, makes a difference in organizational activities and the outcomes of those activities. Leadership has an effect on organizational performance because leadership plays the most important role in mobilizing change in the organization. As Bratton et al (2005:10) stated that the study of leadership must be associated with organizational performance. Daft (2002:300) explains the role of leadership as a relationship builder and leadership as a form of values in the organization. Leadership as a relationship builder plays a role in motivating and empowering, communication, use of influence and power, team leadership, and developing leadership in diversity. Leadership as a form of values in the organization, through vision and determining strategic direction, forming culture and values, designing and leading learning organizations and leading change Transformational leadership according to Yukl (1998:296) refers to the process of building commitment to organizational goals and giving confidence to followers to achieve these goals. Previous studies have always reported that transformational leadership is more effective, productive, innovative, and satisfying for followers as both parties work towards a good organization driven by vision and values as well as mutual trust and respect (Avolio and Bass, 1991; Fairholm, 1991).

This means that transformational leaders believe in formal power sharing and more often practice the use of personal power. Five transformational leadership behaviors that encourage and have a positive impact on the performance of subordinates are the influence of charismatic attribution idealization and behavior, inspirational motivation, intellectual stimulation, and individual consideration. And according to Herminingsih, Anik, Universitas Mercu Buana Jakarta stated that there is a positive and significant influence on transformational leadership on organizational culture as in the journal: "The Effect of Transformational Leadership on Organizational Culture", Scientific Journal of Management Economics and Entrepreneurship "OPTIMAL: Vol. 5, No.1, March 2011 P. 22-37. The Organizational culture is a framework that guides daily behavior in making decisions for employees and directing their actions to achieve organizational goals. Culture must be in line with organizational actions in other parts such as planning, organizing, leadership and 


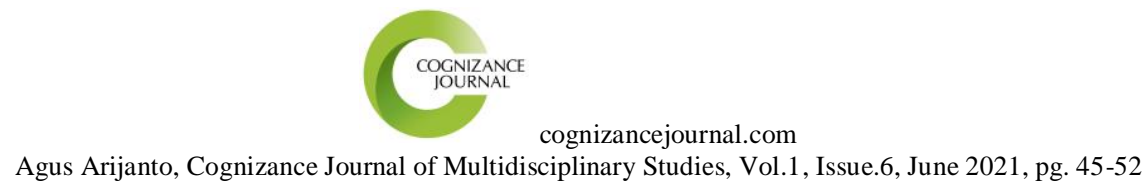

ISSN: 0976-7797

controlling (Rivai, 2011). Organizational Culture Dimensions and Indicators Dimensions and indicators of organizational culture researchers use dimensions and indicators according to Robbins in Badeni (2017), which include: 1) Innovation and risk taking, which includes indicators: a) Innovative b) Be creative 2) Attention to detail, which includes indicators: a) Accuracy b) Analysis c) Paying attention in doing work 3) Outcome orientation, which includes indicators: a) Doing work according to target 4) Team Orientation (Orientation to the team), which includes indicators: a) The success of the team's target 5) Aggressiveness, which includes indicators: a) Aggressive in completing work. 6) Stability, which includes indicators: a) Doing work for the stability of the company. 7) Quality of work, which includes indicators: a) Quality of work b) Results of work.

Organizational Commitment Organizational commitment is the degree to which an employee identifies an organization, its goals, and expectations to remain a member (Robbins and Judge, 2015) Dimensions and Indicators 1) Affective commitment: namely emotional feelings for the organization and belief in its values. 2) Continuance commitment: the perceived economic value of staying in an organization when compared to leaving the organization. an employee may be committed to the employer because he is highly paid and feels that leaving the company will destroy his family. 3) Normative commitment: the obligation to stay in the organization for moral or ethical reasons.

Job satisfaction is a problem that is quite interesting and important, because it has proven to be of great benefit to the interests of individuals, industry and society. For individuals, research on the causes and sources of job satisfaction enables efforts to increase their happiness in life. For industry, research on job satisfaction is carried out in an effort to increase production and influence costs through improving employee attitudes and behavior. Furthermore, the community will certainly enjoy the maximum capacity of the industry as well as the increase in human value in the context of work (Sutrisno, 2014). Dimensions and Indicators of Job Satisfaction To measure the job satisfaction of an employee according to Robbins and Judge in Miftahussudur (2017), namely: 1) The work itself a) Opportunity to learn b) Responsibility 2) Salary or Rewards that are perceived as fair a) Payroll system b) Payroll fairness 3) Promotion Opportunity a) Opportunity to get promotion b) Fairness to get promotion 4) Supervision a) Leaders who are oriented towards employee performance b) Leaders who prioritize employee participation 5) Colleagues a) Support between co-workers b) Working group

Conceptual Framework The conceptual framework in this study aims to obtain research directions that show that there is a relationship between one variable and another, so the conceptual framework can be taken with the line of thought depicted in the structure diagram as shown below:

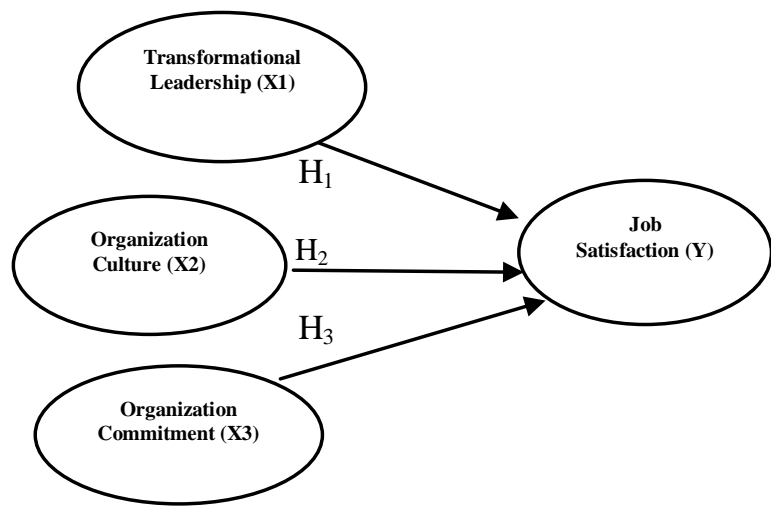

Figure 1. Conceptual Framework

\section{Material AND Method}

The research design in this thesis is associative research. Associative research is research that aims to determine the relationship between two or more variables. This study aims to test the hypothesis about the presence or absence of the influence of one or more variables (independent variables) on other variables (dependent variables). Where this researcher aims to determine the Effect of Transformational Leadership (X1) Organizational Culture (X2) and Organizational Commitment (X3) on Job Satisfaction (Y) Employees at PT.Heriromadiali (Sugiyono, 2016).

Definition and Operational Variable, based on the title of the thesis taken by the author, namely "The Influence of Transformational Leadership, Organizational Culture, and Organizational Commitment to Employee Job Satisfaction at PT. Heriromadiali.", the authors define each variable and make operational variables. 1 . The independent variable is a variable that affects or is the cause of the emergence of the dependent 
variable (Sugiyono, 2013). As for the independent variables in this study and the cause of the emergence of the dependent variable, namely: a. X1 : Transformational Leadership b. X2 : Organizational Culture c. X3 : Organizational Commitment 2. The dependent variable is a variable that is influenced to be a result because of the independent variable (Sugiyono, 2013). In this study, the dependent variable due to the independent variable is: a. Y : Job Satisfaction.

Variable Measurement Scale The Likert scale is a method used to measure attitudes, opinions, and perceptions of a person or group of people about phenomenology (Sugiyono, 2014). Measurement of the variables is done using a Likert scale, which is a measurement method with numbers that are assessed based on levels. Each respondent was asked to indicate his agreement or disagreement with each statement which was given a scale between 1 (strongly disagree) to 5 (strongly agree).

\section{III.RESULT}

Partial Least Square (PLS) Data Analysis Method Convergent Validity

Figure 2 : Partial Least Square (PLS) Data Analysis Method Convergent Validity

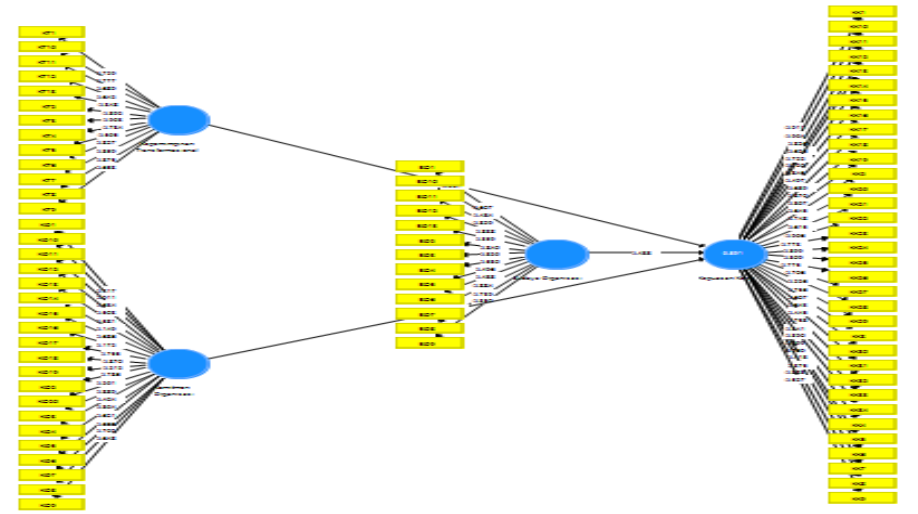

Source: PLS 3.0

Output Based on Figure above, it can be seen that indicators that have a loading factor value of less than 0.50 are declared invalid and insignificant. Therefore, these indicators will be committed from the model.

Table 1 : Convergent Validity (Modification)

\begin{tabular}{ccccc}
\hline & $\begin{array}{c}\text { Organization } \\
\text { Culture (X2) }\end{array}$ & $\begin{array}{c}\text { Transformasional } \\
\text { Leadership (X1) }\end{array}$ & $\begin{array}{c}\text { Job } \\
\text { Satisfaction } \\
(\mathbf{Y})\end{array}$ & $\begin{array}{c}\text { Komitmen } \\
\text { Organisasi } \\
(\mathbf{X 3})\end{array}$ \\
\hline $\begin{array}{c}\text { Organization } \\
\text { Culture (X2) }\end{array}$ & 0,460416667 & & & \\
\hline $\begin{array}{c}\text { Transformationa } \\
\text { 1 Leadership (X1) }\end{array}$ & 0,5625 & 0,515277778 & & \\
\hline $\begin{array}{c}\text { Job SAtisfaction } \\
(\mathbf{Y})\end{array}$ & 0,623611111 & 0,601388889 & 0,48541667 & \\
\hline $\begin{array}{c}\text { Organizational } \\
\text { Commitment } \\
(\mathbf{X})\end{array}$ & 0,3875 & 0,361111111 & 0,48541667 & 0,44583333 \\
\hline Source : PLS 3.0 & & & & \\
\hline
\end{tabular}

The following is the result of eliminating indicators and recalculation. Convergent Validity (Modification) Source: PLS 3.0 . output The results of the modifications in Table and Figure above, it can be seen that all indicators have met convergent validity because they have a loading factor value above 0.50 . Thus, all indicators that have been modified are declared valid. Discriminant Validity.

Discriminant Validity (Modification) After modifying the constructs contained in the modeling, it can be seen from Table at above that several loading factor values for each indicator of each variable already have a loading factor value that is not greater than the loading factor value when associated with other variables. This means that each variable has good discriminant validity where some variables still have a gauge that is highly 
cognizancejournal.com

Agus Arijanto, Cognizance Journal of Multidisciplinary Studies, Vol.1, Issue.6, June 2021, pg. 45-52

ISSN: 0976-7797

correlated with other constructs. Average Variance Extracted (AVE) Test Results Average Variance Extracted (AVE).

Table 2 : Test Results Average Variance Extracted

\begin{tabular}{|c|c|}
\hline Variabel & $\begin{array}{c}\text { Avarage Variance } \\
\text { Extracted (AVE) }\end{array}$ \\
\hline $\begin{array}{c}\text { Organization Culture } \\
(\mathrm{X} 2)\end{array}$ & 0,482638889 \\
\hline $\begin{array}{c}\text { Transformasional } \\
\text { Leadership (X1) }\end{array}$ & 0,427777778 \\
\hline Job Satisfacton(Y) & 0,494444444 \\
\hline $\begin{array}{c}\text { Organization } \\
\text { Commitmen }(\mathrm{X} 3)\end{array}$ & 0,386805556 \\
\hline
\end{tabular}

Source: PLS 3.0 .

Output From Table 2, it can be concluded that the square root of the Average Variance Extracted (AVE) for each construct is greater than the correlation between one construct and another in the model. From the AVE value, the construct in the estimated model meets the discriminant validity criteria Composite Reliability Dan Cronbach's Alpha Composite

Table : 3 Reliability Test Results and Cronbach's Alpha

\begin{tabular}{|c|c|c|}
\hline Variabel & $\begin{array}{c}\text { Composite } \\
\text { Reliability }\end{array}$ & $\begin{array}{c}\text { Cronbach's } \\
\text { Alpha }\end{array}$ \\
\hline Organizational Culture (X2) & 0.939 & 0.921 \\
\hline Transformational Leadership (X1) & 0.946 & 0.937 \\
\hline Job Satisfaction (Y) & 0.978 & 0.975 \\
\hline Organizational Commitment (X3) & 0.945 & 0.936 \\
\hline
\end{tabular}

Based on Table 3 above, it can be seen that the results of the composite reliability test and Cronbach alpha show a satisfactory value, that is, all variables are reliable because all latent variable values have composite reliability values and Cronbach alpha 0.70 . So it can be concluded that the questionnaire used as a research tool has been reliable or consistent.

Table 4 : Hypothesis Testing Results

\begin{tabular}{|l|c|c|c|c|c|}
\hline & $\begin{array}{c}\text { Original } \\
\text { Sampling }\end{array}$ & $\begin{array}{c}\text { Sample } \\
\text { Mean }\end{array}$ & $\begin{array}{c}\text { Standard } \\
\text { Deviation }\end{array}$ & T Statistic & P Values \\
\hline $\begin{array}{l}\text { Organizational Culture } \\
(\mathrm{X} 2) \rightarrow \text { Job Satisfaction } \\
(\mathrm{Y})\end{array}$ & 0.551 & 0.541 & 0.093 & 5.907 & 0.000 \\
\hline $\begin{array}{l}\text { Transformasional } \\
\text { Leadership (X1) } \rightarrow \text { Job } \\
\text { Satisfaction (Y) }\end{array}$ & 0.363 & 0.369 & 0.087 & 4.145 & 0.000 \\
\hline $\begin{array}{l}\text { Organizational } \\
\begin{array}{l}\text { Commitment (X3) } \rightarrow \\
\text { Job Satisfaction (Y) }\end{array}\end{array}$ & 0.100 & 0.112 & 0.046 & 2.179 & 0.030 \\
\hline
\end{tabular}

\section{IV.DISCUSSION}

The Effect of Transformational Leadership on Job Satisfaction

Based on the hypothesis test in this study, the results showed that the T statistic was greater than the T table $(4.145>1.96)$. Thus, the results of hypothesis testing in this study indicate that transformational leadership has a positive and significant effect on job satisfaction for employees of PT Heriromadiali. The results of hypothesis testing in this study can be interpreted that if the application of transformational leadership given to employees increases, the job satisfaction of PT Heriromadiali employees. This shows that if transformational leadership is applied by a leader well, employee job satisfaction will increase towards the company. Transformational leadership is an important thing to consider in an effort to increase employee job satisfaction. companies need to 


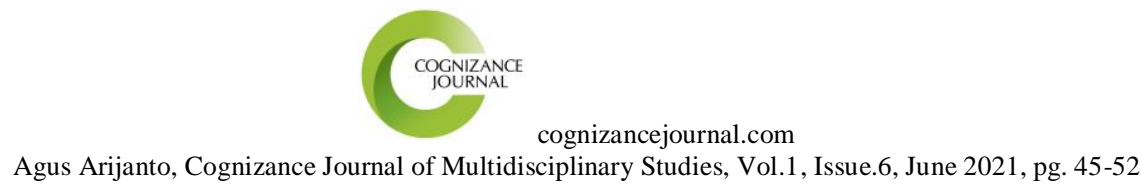

ISSN: 0976-7797

strive to implement transformational leadership because the high and low quality of performance and the good and bad of an employee's performance is influenced by how employees are influenced by the leaders in the company. The results of hypothesis testing in this study are supported by research conducted by Akmal and Danupranata (2015) finding that the influence of transformational leadership on employee job satisfaction shows a significant and positive effect. and also in line with the results of research conducted by Sudibyadnyana and Sintaasih (2018) finding that transformational leadership has a positive and significant effect on job satisfaction.

\section{The Influence of Organizational Culture on Job Satisfaction}

Based on the hypothesis test in this study, the results showed that personality type had a positive and significant effect on job satisfaction because the $T$ statistic was greater than the $T$ table $(5.907>1.96)$. This means that increasing good organizational culture owned by employees can affect job satisfaction for employees of PT Heriromadiali. This shows that if the organizational culture, be it rules, daily behavior, logos, ways of communicating, how to dress, or how to act is compatible with employees, employee job satisfaction will increase as well. The results of hypothesis testing in this study are supported by research conducted by Emami et al. (2012), which shows evidence of a significant positive influence between organizational culture and job satisfaction. and also in line with the results of research conducted by Saputra and Adnyani (2017). Finding that organizational culture has a positive and significant effect on job satisfaction.

\section{The Effect of Organizational Commitment on Job Satisfaction}

Based on the hypothesis test in this study, the results show that Organizational Commitment has a positive and significant effect on job satisfaction because the $\mathrm{T}$ statistic is greater than the $\mathrm{T}$ table $(2.179>1.96)$. From the results of hypothesis testing in this study, it can be interpreted that if the organizational commitment is greater the level of employee commitment and loyalty to the company shows the greater the level of satisfaction felt by employees of PT Heriromadiali. This shows that if the organizational commitment of employees increases, such as being loyal and strong to keep working at the organization, it will affect and increase employee job satisfaction. The results of hypothesis testing in this study are supported by research conducted by Widaglo et al. (2013) Organizational commitment has a significant positive effect on employee job satisfaction and is also in line with the results of research conducted by Desawa and Dwiarta (2015) finding that organizational commitment has an effect on job satisfaction.

\section{Conclusions}

After the researchers conducted research and discussion in the previous chapter regarding the Influence of Transformational Leadership, Organizational Culture, and Organizational Commitment on Job Satisfaction on employees of PT. Heriromadialy, the following conclusions can be drawn:

Transformational Leadership has a positive and significant effect on Job Satisfaction. So it can be interpreted that the higher the application of Transformational Leadership provided by the company to employees, it will also increase Job Satisfaction for SMEs automotive services employees.

Organizational Culture has a positive and significant effect on Job Satisfaction. So it can be interpreted that the better the Organizational Culture owned by the company, it will also increase the Job Satisfaction of SMEs automotive services employees.

Organizational Commitment has a positive and significant effect on Job Satisfaction. So it can be interpreted that the higher the employee's organizational commitment to the company, the higher the job satisfaction for SMEs automotive services employees.

\section{Suggestion Suggestions for Companies}

Based on the results of the description of the respondents' answers, it can be seen from the lowest average value of the transformational leadership variable on the KT5 indicator with a value of 4,044 with the questionnaire statement "The leader in the company gives me encouragement when I experience a decline in work". Therefore, suggestions that can be taken into consideration are that the company is expected to provide support that can motivate inspirational employees. So, employees can be enthusiastic about their work. Based on the results of the description of respondents' answers, it can be seen from the lowest average value of the organizational culture variable on the $\mathrm{BO} 4$ indicator with a value of 3,856 with the statement of the questionnaire "I pay attention to the work I receive in detail". Thus, suggestions that can be taken into consideration are that the company is expected to provide a more detailed or clear job description to employees, which is in accordance with the organizational culture or SOPs within the company. So that it can help employees in completing a job that has been given by the company. Based on the description of respondents' 


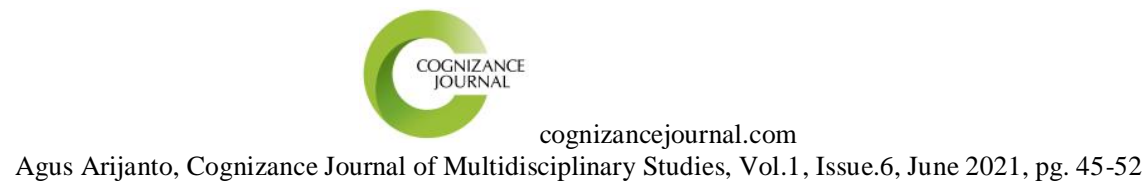

ISSN: 0976-7797

answers, it can be seen from the lowest average value of the Organizational Commitment variable on the KO8 indicator with a value of 3,756 with the statement of the questionnaire "I still believe and be loyal to one organization". For this reason, suggestions that can be taken into consideration for the company are that the company can provide comfort and trust to employees so that they can provide a loyalty to the company.

\section{REFERENCES}

[1]. Akmal, Muhammad. \& Danupranata, Gita. (2015). The Effect of Transformational Leadership on Employee Job Satisfaction at PT. Madubaru PG. PS Madukismo Yogyakarta. Journal of Business Management, Vol 6, No 1.

[2]. Belias, Dimitrios., and Athanasios Koustelios. (2014). Organizational Culture and Job Satisfaction: A Review in University of Thessaly, Karyes, 42100, Tikala, Greece. International Review Of Management and Marketing,4(2), 132-149.

[3]. Denison, D. R. (2010). Corporate Culture and Organizational Effectiveness. John Wiley \& Sons. New York.

[4]. Desawa, Dwi, Aldila and I Made, Bagus, Dwiarta. (2015). The Influence of Organizational Commitment and Job Stress on Employee Job Satisfaction at PT. UNITED MOTORS CENTER Basuki Rahmat Surabaya Branch", Economic Magazine. Vol.20, No.2, Pp.161-176.

[5]. Desseller, Gary. (2015). Human Resource Management, Fourteenth Edition. Salemba Four. Jakarta Eka Saputra,

[6]. I Gede Ade, Adnyani, I Gusti Ayu Dewi., (2017). The Influence of Leadership Style and Organizational Culture on Employee Job Satisfaction Slippery Stone Greek Restaurant and Bar. EJournal of Unud Management, Vol 6, No 12.

[7]. Fahmi, Irfan. (2016). Introduction to Human Resource Management Concepts \& Performance. Media Discourse Partners. Singapore.

[8]. Ghozali, I. (2014). Structural Equation Modeling, Alternative Method With Partial Least Square. Edition 4.Universitas Diponegoro. Semarang.

[9]. Hasibuan, Malay S.P. (2016). Human Resource Management. Revised Edition. Jakarta: Publisher PT Bumi Aksara.

[10].Herawan, Koko., Gunawan, Djudi Mukzam and Nurtjahjono, Eko. (2015). The Influence of Organizational Culture on Employee Job Satisfaction Study at PT. Bank Rakyat Indonesia (PERSERO) Malang Kawi City Branch Office. Journal of Business Administration (JAB), Vol. 1 No. 1.

[11].Herminingsih, Anik "The Effect of Transformational Leadership on Organizational Culture", Scientific Journal of Management Economics and Entrepreneurship "OPTIMAL: Vol. 5, No.1 , Universitas Mercu Buana, March 2011 P. 22-37

[12].Komang Ade Yunita Sari, Wayan Gede Supartha, I Gede Riana, (2017), The Effect of Transformational Leadership on Job Satisfaction and Organizational Commitment (Study in Denpasar City Market Area), E-Journal of Economics and Business, Udayana University, Vol 6, No 1.

[13].Long, C. S., Mardhia, W., Yusof, M., Kowang, T. O., and Heng, L. H., 2014, The Impact of Transformational Leadership Style on Job Satisfaction, World Applied Sciences Journal, 2014, vol. 29, No.1, pp. 117-124, IDOSI Publications, ISSN 1818-4952.

[14].Luthans, Fred. (2006). Organizational Behavior. (Translated by V.A Yuwono, et al), Indonesian Edition, Yogyakarta: ANDI.

[15].Miftahussudur. (2017). Employee Performance Achievement Through Job Satisfaction and Organizational Commitment at the Eastern Group of Bandung City. Thesis. Bandung: Indonesian Computer University (UNIKOM). Retrieved 20 November 2018.

[16].Mochamad Soelton, Muhammad Atnani. (2018), How Work Environment, Work Statisfaction, Work Stress on The Turnover Intention Affect University Management, Indonesian Business Management Journal, Vol. 5, No. 3

[17].Ni Luh Lia Paramita Dewi, I Wayan Bagia, Ni Made Suci, (2017), The Effect of Transformational Leadership and Organizational Commitment on Employee Job Satisfaction at PT PLN (Persero) Rayon Singaraja, Indonesian Management Journal, Vol 8, No 2.

[18].Northouse, P. G. (2013). Leadership. Theory and practice. Sixth edition Jakarta: PT. Index.

[19].Pongpearchan, P.(2016). "Effect of transformational leadership on strategic Human Resources Management and firm success of Toyota's Dealer in Thailand'. Journal of business and retail management research. Vol.10, Issue 2, pp. 53-63. 
[20].Prajuanturi, Mardiki (2017). The Influence of Quality of Work Life and Organizational Commitment on Employee Performance at PT Agung Automall Soekarno Hatta Pekanbaru Branch, JOM FEKON, Vol.4 No.2, Page (2252-2263).

[21].Robbins, Stephen P. (2008). Organizational behavior. Tenth Edition. Complete Edition. Index Publisher. Jakarta. Safitri, Dini.(2017). The Influence of Leadership and Organizational Commitment on Job Satisfaction and Employee Performance of PT Ramajaya Pramukti, Tapung District, Kampar Regency, Riau Province. JOM FEKON, Vol. 4 No.2. Pg (3528-3542).

[22].Sahaya, N. (2012). "A Learning Organization as a Mediator of Leadership Style and Firms' Financial Performance". International Journal of Business and Management. Vol.7, No.14, Pg. 96-113.

[23].Siagian, Sondang P, (2006), Organizational Leadership and Administrative Behavior, Mount Agung Publishers, Jakarta.

[24].Soekidjan. (2009), Human Resource Management. Earth Literature. Jakarta.

[25].Soelton, et al. (2019)., The Role and Impact of Himan Resource Leadership Style and Development In the Organization

[26].Stanislavov, Ivaylo., Ivanov, Stanislav. (2014). The Role of Leadership for Shaping Organizational Culture and Building Employee Engagement in the Bulgarian Gaming Industry. Original Scientific Papers. Vol. 62. No. 1. pp. 19-40.

[27].Sudibyadnyan Putu, Sintaasih, Desak Ketut, (2018). The Influence of Transformational Leadership and Empowerment on Job Satisfaction of Public Bureau Employees and Protocols of the Bali Provincial Secretariat. E-Journal of Unud Management, Vol 7, No 1.

[28].Sugiyono. (2016), Quantitative, Qualitative, and R\&D Research Methodology, CV Alfabeta. Jakarta. Sunyoto,

[29].Wibowo. (2010), Performance Management, Rajawali Press, Jakarta. Widagdo., et al. (2013), Effect of Organizational Culture and Organizational Commitment on Employee Job Satisfaction at PT. Nutrifood Indonesia In Jakarta. Indonesian Science Management Research Journal (JRMSI), Vol.4, No.1. Yukl, G. (2010). Leadership in Organizations. Prentice-Hall. New Jersey. 